\title{
MEDIA AUDIOVISUAL TENTANG FARDHU 'AIN (SUBUH, ZUHUR, 'ASAR, MAGHRIB, DAN ISYA) PADA PELAJARAN FIQIH SISWA KELAS VI MADRASAH IBTIDAIYAH NEGERI 7 LANGKAT BOHOROK
}

\author{
Muhijar \\ Surel: muhijarijar22@gmail.com
}

\begin{abstract}
Audiovisual media about Fardhu 'Ain (Fajr, Zuhur,' Asar, Maghrib, and Isya) can improve the results of Islamic Fiqh Lessons for Class VI Madrasah Ibtidaiyah Negeri 7 Langkat Bohorok, this can be seen from the calculation results in the first cycle between the first prayer practice test scores. with the second prayer practice test value obtained Product Correlation Moment $r$ count of 0.780 and the t test value of 6.20, and in the second cycle between the third prayer practice test value and the fourth prayer practice test value obtained Product Correlation Moment $r$ count 0.870 and test value t of 8.72. Audiovisual Media About Fardhu 'Ain (Fajr, Zuhur,' Asar, Maghrib, and Isya) can increase the activities of Class VI Students at Madrasah Ibtidaiyah Negeri 7 Langkat Bohorok, this can be seen from the presence of students before the classroom research action is done by $85 \%$, the first cycle The presence of students after the classroom research action was $90 \%$, the first cycle of student attendance after the classroom research action was $95 \%$, the second cycle the attendance of students after the classroom research action was 100\%.
\end{abstract}

Keywords: Audiovisual Media About Fardhu 'Ain (Fajr, Zuhur, 'Asar, Maghrib, and Isha)

\begin{abstract}
ABSTRAK
Media Audiovisual Tentang Fardhu 'Ain (Subuh, Zuhur, 'Asar, Maghrib, dan Isya) dapat meningkatkan hasil Pelajaran Fiqih Siswa Kelas VI Madrasah Ibtidaiyah Negeri 7 Langkat Bohorok, hal ini dapat dilihat dari hasil hitung pada siklus pertama antara nilai test praktek sholat pertama dengan nilai test praktek sholat kedua diperoleh Korelasi Produk Moment $\mathrm{r}$ hitung sebesar 0,780 dan nilai uji t sebesar 6,20, dan pada siklus kedua antara nilai test praktek sholat ketiga dengan nilai test praktek sholat keempat diperoleh Korelasi Produk Moment $r$ hitung sebesar 0,870 dan nilai uji t sebesar 8,72. Media Audiovisual Tentang Fardhu 'Ain (Subuh, Zuhur, 'Asar, Maghrib, dan Isya) dapat meningkatkan aktivitas Siswa Kelas VI Madrasah Ibtidaiyah Negeri 7 Langkat Bohorok, hal ini dapat dilihat dari kehadiran siswa sebelum dilakukannya tindakan penelitian kelas sebesar $85 \%$, siklus pertama kehadiran siswa setelah dilakukannya tindakan penelitian kelas sebesar $90 \%$, siklus pertama kehadiran siswa setelah dilakukannya tindakan penelitian kelas sebesar 95\%, siklus kedua kehadiran siswa setelah dilakukannya tindakan penelitian kelas sebesar $100 \%$.
\end{abstract}

Kata Kunci: Media Audiovisual Tentang Fardhu 'Ain (Subuh, Zuhur, 'Asar, Maghrib, dan Isya)

\section{PENDAHULUAN}

Pendidikan Islam adalah suatu proses bimbingan yang secara sadar dilakukan guru untuk menciptakan kepribadian muslim yang aspek jasmani dan rohani peserta didiknya berkembang dan berubah menjadi lebih baik, dan dengan proses bimbingan tersebut diharapkan mampu melahirkan seorang muslim yang berakhlak mulia dan taat kepada ajaran-ajaran Islam.

Tujuan pendidikan Islam yaitu memperhambakan diri kepada Allah, 
dan hanya beribadah kepada-Nya secara baik dan benar menurut tuntunan syariah. Dalam tujuan pendidikan agar tugas-tugas kehambaan atau peribadatan dapat terselenggara sebagaimana mesti nya, maka pendidikan Islam seyogiaya nya ditujukan untuk mempersiapkan peserta didiknya menjadi seorang hamba Allah yang bergelar `abd Allah. Pendidikan ditujukan untuk mempersiap kan peserta didik agar dapat melaksana kan tugas dan tanggung jawabnya secara baik dan benar selaku khalifa Allah di bumi.

Seorang guru bertugas sebagai pendidik, mendidik adalah tugas yang amat luas. Mendidik itu sebagian dilakukan dalam bentuk mengajar, dalam bentuk memberikan dorongan, memuji, menghukum, memberi contoh, membiasakan, dan lain-lain. Dalam proses belajar mengajar guru diharap kan dapat menjalani tugasnya baik itu tugas membuat persiapan mengajar, tugas mengevaluasi hasil belajar, dan lain-lain yang bersangkutan dengan pencapaian tujuan pengajaran tersebut.

Metode pembelajaran dalam kegiatan proses pembelajaran merupa kan hal yang sangat penting dalam meningkatkan mutu belajar, karena dengan metode yang bervariasi guru dapat menciptakan suasana belajar yang mendukung sehingga tujuan pembelajaran tercapai.

Dalam proses pembelajaran di harapkan seorang guru mampu meng gunakan media pembelajaran, dimana dengan adanya media guru diharapkan juga menjadi fasilitator, guru dapat menyediakan media-media, salah satu nya dengan menggunakan media audiovisual.

Dengan menjadi fasilitator guru akan dapat menciptakan pembelajaran aktif, yaitu merupakan proses pem belajaran dimana seorang guru harus dapat menciptakan suasana yang sedemikian rupa sehingga siswa aktif bertanya, mempertanyakan dan juga mengemukakan gagasannya. Selain itu guru juga harus dapat membuat proses pembelajaran yang menyenangkan se hingga siswa dapat memusatkan per hatiannya secara penuh pada belajarnya.

Media audiovisual merupakan media yang menarik dimana dalam proses pembelajaran media pendengar an (media audia) dan media penglihatan (media visual) dapat mempercepat daya serap siswa dalam memahami pem belajaran yang disampaikan oleh guru nya. Dengan media audiovisual guru dapat membuat tampilan semenarik mungkin, agar siswa tertarik untuk mengikuti pembelajaran.

Siswa kelas VI Madrasah Ibtidaiyah Negeri 7 Langkat Bohorok merupakan siswa yang mulai beranjak remaja, diperkirakan umur siswa ratarata 13 tahun. Sebagian siswa ada yang sudah akil balig, dimana saatnya siswa harus mempelajari hal-hal yang wajib maupun sunat. Hendaknya siswa memahami fardhu 'ain (wajib pribadi) dan fardhu kifayah (wajib bersama), seperti: sholat fardhu 'ain (Subuh, Zuhur, 'Asar, Maghrib, dan Isya), sholat Fardhu kifayah (sholat jenazah). 


\section{SCHOOL EDUCATION JOURNAL VOLUME 10 NO. 4 DESEMBER 2020}

Seorang guru dituntut untuk mengajarkan sholat fardhu 'ain (Subuh, Zuhur, 'Asar, Maghrib, dan Isya), dan sholat Fardhu kifayah (sholat jenazah) dengan metode praktek langsung kepada siswa, agar siswa mengerti dan memahami bagaimana cara mengerja kan sholat tersebut. Dalam hal ini metode atau media yang tepat diguna kan oleh seorang guru adalah media audiovisual, dimana guru akan menam pilkan praktek langsung pelaksanaannya melalui vidio tentang sholat jenazah yang ditayangkan dan dilihat bersama-sama oleh siswa.

Tujuan dari penelitian ini adalah untuk mengetahui Media Audiovisual Tentang Fardhu 'Ain (Subuh, Zuhur, 'Asar, Maghrib, dan Isya) dapat meningkatkan hasil belajar Fiqih dan aktivitas Siswa Kelas VI Madrasah Ibtidaiyah Negeri 7 Langkat Bohorok.

\section{METODE PENELITIAN}

Penelitian tindakan kelas (PTK) ini dilaksanakan dalam dua siklus selama satu bulan di kelas VI Madrasah Ibtidaiyah Negeri 7 Langkat Bohorok yang beralamat di jalan Ampera pekan Bohorok kabupaten Langkat Sumatera Utara, dengan jumlah siswa sebanyak 26 orang.

Pada Media audiovisual ini siswa dibagi menjadi beberapa kelompok dengan anggota sebanyak 5 sampai 8 orang. Dimana tiap kelompoknya bersifat hiterogen, yang terdiri dari pria dan wanita. Anggota team diberi nomor, dan masingmasing yang mendapat nomor akan dibimbing dan di arahkan cara mengerjakan sholat secara bersama oleh anggota kelompoknya. Sementara guru mempersiapkan perangkat pembelajaran berupa; RPP, materi ajar, buku paket, soal-soal, alat-alat pembelajaran dan penilaian, dan yang lainnya.

Prosedur kerja, dalam penelitian ini, dilakukan terdiri dari dua siklus dan 10 pertemuan (20 jam). Kegiatan awal dua kali pertemuan, memberikan bimbingan cara mengambil wudhu sebelum melaksanakan sholat. Setelah kegiatan pada siklus I berlangsung selama empat kali pertemuan tentang bacaan yang ada dalam sholat, selanjutnya diikuti oleh kegiatan pada siklus II selama tiga kali pertemuan tentang praktek sholat dengan Media audiovisual sampai siswa benar-benar memahami cara sholat yang baik dan sesuai dengan aturan yang terdapat pada pelajaran Fiqih, dan pengelolaan nilai selama satu kali pertemuan, dengan rincian sebagai berikut:

Pertama, guru membagi siswa sesuai dengan kelompok yang telah disepakati, dan memberikan pengarahan kepada siswa tentang pelaksanaan sebelum dan sesudah siklus I dan II dengan terlebih dahulu melakukan percobaan awal tentang mengambil air wudhu sebelum kegiatan dilaksanakan (pertemuan pertama), selanjutnya pada pertemuan berikutnya guru membahas materi pelajaran dengan model pembelajaran (siklus pertama yaitu Media audiovisual), setelah melaksana kan aktifitas pembelajaran tentang bacaan yang dibaca saat sholat 
ber langsung kepada siswa dan dilakukan lah praktek sholat pertama dan kedua (siklus I pertemuan kedua dan keempat) untuk mengetahui sampai dimana kemampuan yang dimiliki siswa dalam memahami materi yang diajarkan guru).

Pengamatan (Observasi), selama berlangsung pembelajaran di dalam kelas, guru yang lain melakukan pengamatan hal-hal yang terjadi, apa saja kegiatan yang dilakukan siswa, apakah sudah sesuai dengan yang direncanakan sebelumnya, disamping itu peneliti sebagai guru pembimbing bertindak juga sebagai pengamat.

Refleksi, hasil pengamatan pada siklus I dimaksudkan untuk mengetahui apa saja kelemahan yang dihadapi siswa dalam memecahkan masalah saat melakukan praktek sholat pertama, dan dikumpul kan serta dianalisa, sehingga dapat disimpulkan langkah-langkah apa yang akan diambil untuk siklus berikutnya.

Kedua, siswa diberikan penjelasan tentang materi bagaimana cara sholat wajib (fardhu 'ain) yang sesuai dengan aturan yang telah ditetapkan dalam Al Qur'an dan Hadis, yang mana proses pembelajaran di siklus II menggunakan Media audiovisual, Memasuki per- temuan ketujuh barulah pembelajaran menjadi terarah, dan siswa sudah mampu memecahkan sendiri masalah -masalah yang ada. Untuk mengetahui sampai dimana aktifitas siswa dilakukanlah praktek sholat ketiga dan keempat (siklus II pertemuan keenam dan kedelapan) tentang melaksanakan sholat wajib dengan baik dan sempurna.

Pengamatan

(Observasi), sedikit sekali ditemuinya kelemahan yang dihadapi oleh siswa dalam memecah kan masalah di siklus II ini, siswa sudah memahami dan mengerti tentang materi sholat wajib pada pelajaran fiqih, sehingga peneliti sebagai guru pembimbing bertindak juga sebagai pengamat pada siklus II memutuskan untuk tidak melanjutkan penelitian ini ke siklus berikutnya.

Refleksi, tidak adanya temuan kelemahan pada siklus II saat tindakan berlangsung untuk praktek sholat wajib pada mata pelajaran Fiqih dengan Media audiovisual, dan menghasilkan nilai belajar Fiqih serta keaktifan siswa sudah cukup bagus, maka peneliti tidak perlu lagi melanjutkan penelitian ini.

Metode pengumpulan data, pada penelitian ini data diperoleh dari siswa/siswi kelas VI Madrasah Ibtidaiyah Negeri 7 Langkat, berupa nama-nama siswa, nilai harian yang diambil dari hasil test awal pada awal kegiatan penelitian, dan test akhir dilaksanakan sebanyak dua kali yaitu test awal praktek sholat wajib setelah selesai kegiatan pada siklus I, dan test akhir praktek sholat wajib setelah selesai kegiatan pada siklus II dengan Media audiovisual. Sementara aktivitas siswa diperoleh dari kehadiran siswa dalam mengikuti pembelajaran selama proses penelitian.

Metode analisis data, pengelolaan data dalam penelitian ini meng- gunakan teknik analisis data 
secara kuantitatif (perhitungan) dengan statistik deskriftif, dan untuk mencari nilai rata-rata (mean), simpangan baku (standar deviasi), dan nilai korelasi (produc moment).

\section{HASIL PENELITIAN DAN} PEMABAHASAN

Setelah

penelitian

dilaksanakan selama dua siklus dengan menggunakan Media audiovisual, diperoleh hasil dari praktek sholat wajib yang dilaksanakan empat kali yaitu praktek pertama cara mengambil wudhu, praktek kedua membaca bacaan dalam sholat, praktek ketiga melaksanakan sholat, praktek sholat keempat membaca doa yang di baca setelah selesai sholat. Hal ini dapat dilihat pada tabel berikut:

Tabel 1. Hasil Belajar Praktek Sholat Fardu 'Ain (Subuh, Zuhur, 'Asar, Maghrib, dan Isya) Pada Pelajaran Fiqih Siswa Kelas VI Madrasah Ibtidaiyah Negeri 7

Langkat Bohorok

\begin{tabular}{c|l|c|c|c|c}
\hline \multirow{2}{*}{ NO NAMA SISWA } & \multicolumn{4}{|c}{ Nilai Hasil Belajar Praktek Sholat } \\
\cline { 3 - 6 } & & \multicolumn{4}{|c}{ Fardu 'Ain } \\
\cline { 3 - 6 } & & Pertama & Kedua & Ketiga & Keempat \\
\hline 1 & Ade Suci Ramadhani Purba & 62 & 64 & 75 & 80 \\
\hline 2 & Adha Setiawan & 78 & 80 & 82 & 84 \\
\hline 3 & Adi Sanjaya & 80 & 82 & 84 & 86 \\
\hline 4 & Ahmad Edi Pirmanta Ginting & 81 & 83 & 85 & 87 \\
\hline 5 & Arbi Syahputra & 82 & 84 & 86 & 88 \\
\hline 6 & Ardiansyah & 62 & 64 & 74 & 80 \\
\hline 7 & Ayu Kristiani & 77 & 80 & 82 & 84 \\
\hline 8 & Chikita Az Zahra & 80 & 81 & 83 & 85 \\
\hline 9 & Dinda Paradila Pane & 78 & 80 & 82 & 84 \\
\hline 10 & Elsa Adela & 82 & 84 & 86 & 88 \\
\hline 11 & Fachrizal Agam Meutuah & 80 & 82 & 84 & 86 \\
\hline 12 & M. Alfin & 81 & 83 & 85 & 87 \\
\hline 13 & Muslimaini & 83 & 85 & 86 & 89 \\
\hline 14 & Nayla Nazmi Tahapary & 78 & 80 & 82 & 84 \\
\hline 15 & Nazwa Al Qusairi & 78 & 80 & 82 & 84 \\
\hline 16 & Raini Suri & 64 & 75 & 81 & 83 \\
\hline 17 & Rifqi Ardiansah. AS & 78 & 80 & 82 & 83 \\
\hline 18 & Risya Sahdaini Br Sembiring & 81 & 83 & 85 & 87 \\
\hline 19 & Siti Nabila Br Ginting & 82 & 84 & 86 & 89 \\
\hline 20 & Sholihin & 64 & 73 & 78 & 83 \\
\hline 21 & Topan Lesmana Putra Sitepu & 80 & 82 & 84 & 86 \\
\hline 22 & Uswatun Hasanah & 78 & 80 & 82 & 84 \\
\hline 23 & Yazid Anshori Sani & 83 & 85 & 86 & 88 \\
\hline 24 & Zahra Mutiara Ningsih & 85 & 87 & 88 & 91 \\
\hline 25 & Zaskia Anggrela Friji & 80 & 82 & 84 & 86 \\
\hline 26 & Zuyyina Tsuwaiba & 78 & 81 & 83 & 85 \\
\hline & & 77,5 & 80,15 & 82,96 & 85,42 \\
\hline & $\quad$ Nilai Rata - Rata & 6,48 & 5,47 & 3,2 & 2,59 \\
\hline & & & & & \\
\hline
\end{tabular}


Muhijar : Media Audiovisual Tentang Fardhu 'Ain ...

\section{Pembahasan}

Gambaran hasil penelitian yang dilaksanakan di kelas VI Madrasah Ibtidaiyah Negeri 7 Langkat Bohorok yang jumlah siswanya sebanyak 26 orang, secara umum menunjukkan hasil yang sangat menggembirakan, dengan rincian sebagai berikut; tes praktek sholat pertama (cara mengambil wudhu) pada pelajaran Fiqih sebelum dilaksana kannya tindakan menghasilkan nilai rata-rata sebesar 77,5 dan 4 siswa $(15,38 \%)$ tidak tuntas, dengan simpangan baku sebesar 6,48, sementara nilai kriteria ketuntasan minimum (KKM) sebesar 65 , ini artinya walaupun hasil belajar Fiqih siswa sudah di atas KKM namun masih ada 4 siswa yang harus remedial. Berikutnya, dilaksanakan kegiatan pembelajaran menggunakan Media Audiovisual pada mata pelajaran Fiqih materi tentang Sholat wajib pada silkus I dan dilakukan tes praktek sholat kedua (bacaan dalam sholat), menghasilkan nilai rata-rata sebesar 80,15 dan 2 siswa $(7,69 \%)$ tidak tuntas, dengan simpangan baku sebesar 5,47, ini artinya walaupun hasil belajar Fiqih siswa sudah di atas nilai KKM, namun demikian masih ada 4 siswa masih remedial. Pada silkus II dan dilakukan tes praktek sholat ketiga (pelaksanaan sholat wajib), menghasil kan nilai rata-rata sebesar 82,96 dan 0 siswa (0\%) tidak tuntas, dengan simpangan baku sebesar 3,20, ini artinya hasil belajar Fiqih siswa sudah di atas nilai KKM (tuntas). Dan tes praktek sholat keempat (pelaksanaan sholat disertai doa setelah sholat), menghasilkan nilai rata-rata sebesar 85,42 dan 0 siswa (0 $\%)$ tidak tuntas, dengan simpangan baku sebesar 2,59, ini artinya hasil belajar Fiqih siswa sudah di atas nilai KKM (tuntas).

Selanjutnya, Nilai rata-rata dari hasil hitung siklus pertama maupun siklus kedua akan dibuat ke bentuk diagram batang dan diagram garis yang dapat dilihat sebagai berikut:

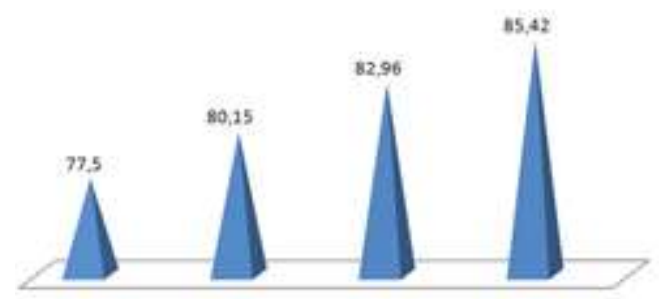

\section{Gambar 1. Diagram Batang Nilai Rata-Rata Siklus I}

Diagram batang di atas nilai rata-rata dari hasil hitung siklus pertama untuk nilai tes praktek sholat pertama (cara mengambil wudhu) sebesar 77,5 dan nilai tes praktek sholat kedua (bacaan dalam sholat) sebesar 80,15 selisihnya sebesar 3,35, serta siklus kedua untuk tes praktek sholat ketiga (pelaksanaan sholat wajib), sebesar 82,96 dan tes praktek sholat keempat (pelaksanaan sholat disertai doa setelah sholat) sebesar 85,42 selisihnya sebesar 2,46 , hal ini menunjukkan nilai tersebut semakin meningkat (tinggi). Artinya, semakin tinggi nilai rata-rata, maka semakin meningkat rentangan nilai tersebut, ini menunjukkan semakin sangat baik hasil belajar mata pelajaran Fiqih materi tentang Sholat jenazah dan yang lainnya di kelas VI Madrasah 
Ibtidaiyah Negeri 6 Langkat dan nilai rata-rata tersebut semakin sangat baik.

Selanjutnya, Nilai simpangan baku dari hasil hitung siklus pertama maupun siklus kedua yang akan dibuat ke bentuk diagram batang dan diagram garis yang dapat dilihat sebagai berikut ;

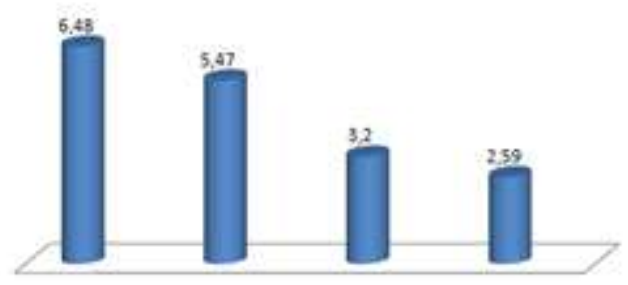

\section{Gambar 2. Diagram Batang Nilai Simpangan Baku Siklus I}

Diagram batang di atas nilai simpangan baku dari hasil hitung siklus pertama untuk nilai tes praktek sholat pertama (cara mengambil wudhu) sebesar 6,48 dan nilai tes praktek sholat kedua (bacaan dalam sholat) sebesar 5,47 selisih sedikit sebesar 1,01, serta siklus kedua untuk tes praktek sholat ketiga (pelaksanaan sholat wajib) sebesar 3,2 dan tes praktek sholat keempat (pelaksanaan sholat disertai doa setelah sholat) sebesar 2,59 selisih sedikit sebesar 0,61 , hal ini menunjukkan nilai tersebut semakin menurun (rendah). Artinya, semakin rendah nilai simpangan baku, maka semakin kecil rentangan nilai tersebut, ini menunjukkan semakin sangat baik. Dan nilai simpangan baku tersebut semakin sangat baik.

Untuk melihat adanya korelasi atau hubungan diperlukan rumus produc moment dengan hasil sebagai berikut: korelasi antara nilai hasil belajar Fiqih siswa pada pre tes atau test awal (sebelum tindakan) terhadap nilai hasil belajar Fiqih siswa pada ujian blok I (tindakan siklus I) sebesar 0,780 (kategori cukup signifikan) dengan nilai uji $\mathrm{t}$ sebesar 6,20, dan korelasi antara nilai hasil belajar Fiqih siswa pada ujian blok II (tindakan siklus I) terhadap nilai hasil belajar Fiqih siswa pada ujian blok III (tindakan siklus II) sebesar 0,87 (kategori sangat signifikan) dengan nilai uji t sebesar 8,72 .

\section{Pembahasan}

Setiap metode yang kita pilih tentu memiliki kelebihan dan kekurangannya masing-masing. Adapun kelebihan media audiovisual dalam proses pembelajaran: Kelebihan media dari media ini ialah dapat memberikan suasana yang lebih hidup penampilannya lebih menarik dan disamping itu dapat digunakan untuk memperlihatkan suatu proses tertentu secara lebih nyata, penggunaannya tidk menggunakan ruangan yang gelap, menghemat waktu dan rekaman dapat diputar berulang-ulang, penggunaan media ini memecahkan aspek verbalisme pada diri siswa.

Selain kelebihan media audiovisual, ada juga kelemahan media audiovisual dalam proses pembelajaran yaitu: Kelemahan media ini, terutama terletak dalam segi teknis dan juga biaya. Penggunaan media ini memerlukan dukungan sarana dan prasarana tertentu seperti listrik serta peralatan atau bahan-bahan khusus yang tidak selamanya mudah diperoleh ditempat-tempat tertentu, Pengadaan maupun pemeliharannya 
Muhijar : Media Audiovisual Tentang Fardhu 'Ain ...

cenderung menuntuk pembiayaan yang mahal, Kurang mampu menampilkan detail dari objek yang disajikan secara sempurna, Memerlukan peralatan yang mahal dan kompleks.

\section{SIMPULAN}

Berdasarkan beberapa penjelasan sebelumnya, penulis menyimpulkan sebagai berikut: Media Audiovisual Tentang Fardhu 'Ain dapat meningkatkan hasil Pelajaran Fiqih Siswa Kelas VI Madrasah Ibtidaiyah Negeri 7 Langkat Bohorok, hal ini dapat dilihat dari hasil hitung pada siklus pertama antara nilai Test praktek sholat pertama dengan nilai Test praktek sholat kedua diperoleh Korelasi Produk Moment $\mathrm{r}$ hitung menunjukkan nilai positif sebesar 0,780 dan uji $\mathrm{t}$ menunjukkan nilai positif sebesar 6,20 , dan pada siklus kedua antara nilai Test praktek sholat ketiga dengan nilai Test praktek sholat keempat diperoleh Korelasi Produk Moment $r$ hitung menunjukkan nilai positif sebesar 0,870 dan uji $t$ menunjukkan nilai positif sebesar 8,72. Media Audiovisual Tentang Fardhu 'Ain dapat meningkatkan aktivitas Siswa Kelas VI Madrasah Ibtidaiyah Negeri 7 Langkat Bohorok, hal ini dapat dilihat dari kehadiran siswa sebelum dilakukannya tindakan penelitian kelas sebesar $85 \%$, siklus pertama kehadiran siswa setelah dilakukannya tindakan penelitian kelas sebesar 90\%, siklus pertama kehadiran siswa setelah dilakukannya tindakan penelitian kelas sebesar 95\%, siklus kedua kehadiran siswa setelah dilakukannya tindakan penelitian kelas sebesar $100 \%$.

\section{DAFTAR RUJUKAN}

Arif, ArmaI. 2002. Pengantar Ilmu dan Metodologi Pendidikan Islam. Jakarta: Ciputat Press.

Arikunto, Suharsimi. 2006. Dasardasar Evaluasi Pendidikan. Jakarta: Bumi Aksara.

Arsyad, Azhar. 2007. Media Pembelajaran. Jakarta: Rajawali Perss.

Basyiruddin M. dan Asnawir. 2002. Media Pembelajaran. Jakarta: Ciputat Press.

Dimyati dan Mudjiono. 2006. Belajar dan Pembelajaran. Jakarta: Rineka cipta.

Hafsah. 2011. Fiqih. Bandung: Cita Pusta Media Perintis.

Hamalik, Oemar. 1999. Media Pendidikan. Bandung: Citra Aditya Bakti.

Kunandar. 2008. Langkah Mudah Penelitian Tindakan Kelas Sebagai Pengembangan Profesi Guru. Jakarta: Raja Grapindo Persada.

Najmuddin. A.R, Wahid. Tuntunan Shalat Wajib dan Sunnah, (Yogyakarta: Kudsi Media, 2009)

Sadili, Ahmad Nawawi. 2009. Panduan peraktis Salat Fardu dan Sunnah. Jakarta: Amzah.

Slameto. 2005. Penilaian Hasil Belajar Mengajar. Bandung: Remaja Rosda karya 